\title{
During this Bowel Movement
}

National Cancer Institute

\section{Source}

National Cancer Institute. During this Bowel Movement. NCI Thesaurus. Code C129756.

Occurring in the course of the current bowel movement. 